\title{
Translation, reliability, agreement and validity of the Turkish version of Cumulated Ambulation Score in patients with hip fracture
}

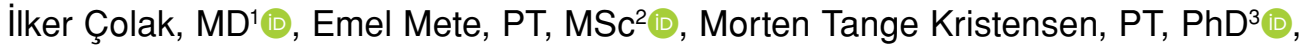 \\ Tuğba Kuru Çolak, PT, $\mathrm{PhD}^{4}$ (] \\ ${ }^{1}$ Department of Orthopedics and Traumatology, Dr. Lütfi Kırdar Kartal Training and Research Hospital, Istanbul, Turkey \\ ${ }^{2}$ Department of Physiotherapy and Rehabilitation, Istanbul Medeniyet University, Faculty of Healthy Sciences, Istanbul, Turkey \\ ${ }^{3}$ Departments of Physical Therapy and Orthopedic Surgery, Physical Medicine and Rehabilitation Research-Copenhagen (PMR-C), \\ Amager-Hvidovre Hospital, University of Copenhagen, Copenhagen, Denmark \\ ${ }^{4}$ Department of Physiotherapy and Rehabilitation, Marmara University, Faculty of Healthy Sciences, Istanbul, Turkey
}

Several risk factors associated to hip fractures have been identified. Among these factors, the age is the most important one. ${ }^{[1]}$ The world's elderly population is growing faster than all other age groups. The World Health Organization reported that the number of people aged 65 years and over will be 1.5 billion by 2050, representing $16 \%$ of world's population. ${ }^{[2]}$ Hip fractures remain important health problems, both for individuals and for health systems. It is a major cause of disability, dependency and death in the elderly. ${ }^{[3-5]}$ After hip-fracture surgery, physical functions of the vast majority of patients are impaired. ${ }^{[6,7]}$

With early rehabilitation and independent mobility after a hip fracture, secondary complications that may cause disability and mortality may be reduced. It is essential to assess mobility level in early postoperative period. Cumulated Ambulation Score (CAS) is a simple test defined to assess basic mobility skills that include getting in and out of bed,

Received: April 17, 2020

Accepted: May 05, 2020

Published online: June 18, 2020

Correspondence: Illker Çolak, MD. Dr. Lütfi Kırdar Kartal Eğitim ve Arasstırma Hastanesi Ortopedi ve Travmatoloji Kliniği 34890 Kartal, İstanbul, Türkiye

E-mail: drilkercolak@hotmail.com

Doi: $10.5606 /$ ehc. 2020.75526

Citation: Çolak I, Mete E, Kristensen MT, Kuru Çolak T. Translation, reliability, agreement and validity of the Turkish version of Cumulated Ambulation Score in patients with hip fracture. Jt Dis Relat Surg 2020;31(2):346-352.

\section{ABSTRACT}

Objectives: This study aims to translate and investigate the interrater reliability, agreement and validity of the Turkish version of the Cumulated Ambulation Score (CAS-TR) in patients with hip fracture.

Patients and methods: This study included patients with a hip fracture of the femoral neck between July 2019 and March 2020 at the Dr. Lütfi Kırdar Kartal Training and Education Hospital, Department of Orthopedics and Traumatology, Istanbul. The CAS manual and score-sheet were translated into Turkish. An orthopedician and a physiotherapist independently administered the CAS-TR to 36 patients (12 males, 24 females; mean age 78.7 years; range, 65 to 90 years) at postoperative days one, two, three and 30. Weighted Cohen's kappa coefficient was used to measure inter-rater reliability. Turkish version of modified Barthel Index was used for analysis of validity.

Results: The majority of the patients had type III fracture (72.2\%) according to Garden's classification. The kappa value was $\geq 0.90$ for days one-three, the total and $30^{\text {th }}$ day score of CAS-TR. The observed agreement ranged between $91.6 \%$ and $100 \%$ for all assessments. Validity analysis showed a significantly positive correlation between day two and day 30 CAS-TR and Barthel scores.

Conclusion: We found almost perfect reliability, high percentage agreement and acceptable convergent validity of the CAS-TR. We recommend the CAS to be used as an easily applicable instrument to assess basic mobility status in Turkish patients with hip fracture. Orthopedic and geriatric patients and patients undergoing any type of surgery can be assessed with CAS for early evaluation of mobility status.

Keywords: Arthroplasty, femoral neck fracture, hip, mobility.

rise from a chair and walk around indoor with an appropriate walking aid. ${ }^{[8,9]}$ Independence in these three physical functions is essential for the patient's ability to be discharged to their own homes. Previous 
studies reported that CAS can be a predictor for postoperative outcomes in relation to length of hospitalization, discharge home, occurrence of larger medical complications in addition to short- and long-term mortality after a hip fracture.$^{[8,10,11]}$ and used as an outcome in other studies. ${ }^{[12,13]}$ The CAS was developed in Denmark and first published by Foss et al. ${ }^{[8]}$ in 2006, and examined for reliability and described in details by Kristensen et al. ${ }^{[9]}$ in 2009. The CAS has been published in scientific journals in English, ${ }^{[9]}$ Italian $^{[14]}$ and Spanish ${ }^{[15]}$ languages, but it is also available in Swedish, Norwegian and Indonesian-Bahasa languages at ResearchGate. Additionally, versions in Portuguese, Japanese, French, Estonian, Dutch and Spanish-Argentinian languages are in preparation.

In clinical practice and research studies, valid tools are needed to assess the mobility level objectively for elderly patients. Therefore, in this study, we aimed to translate and investigate the inter-rater reliability, agreement and validity of the Turkish version of the Cumulated Ambulation Score (CAS-TR) in patients with hip fracture.

\section{PATIENTS AND METHODS}

This study included patients with a hip fracture of the femoral neck between July 2019 and March 2020 at the Dr. Lütfi Kırdar Kartal Training and Education Hospital, Department of Orthopedics and Traumatology, Istanbul. Fifty-seven patients with femoral neck fracture were admitted to the department during the study period. Of these, six patients died, six patients had accompanying fractures, four patients did not return for day 30 assessment, three had neurologic disorder, and two refused to participate in the study, and thus 36 patients (12 males, 24 females; mean age 78.7 years; range, 65 to 90 years) participated in the study. The study protocol was approved by the Marmara University, Faculty of Health Sciences Ethics Committee (27.06.2019/77). A written informed consent was obtained from each patient. The study was conducted in accordance with the principles of the Declaration of Helsinki.

The inclusion criteria were as follows: hip hemiarthroplasty treatment for femoral neck fracture, which allows immediate unrestricted weight bearing, being aged 65 years and older and walking ability (independent walking with or without walking aid) before the fracture. Patients were excluded from the study if they had hip fractures of other etiology (trochanteric or subtrochanteric), concomitant fractures in upper or lower extremity, total hip replacement, any rheumatological or neurological disease, or any mental disorder. Femoral neck fractures were classified according to Garden's classification. ${ }^{[16]}$

The CAS measures the level of independence in (i) getting in and out of bed (from supine in bed to sitting on the side at the bed, to standing or transfer to sitting in chair placed beside the bed, and return to the supine position in the bed), (ii) sit-to-stand from a chair with armrests (from sitting to standing to sitting) and (iii) indoors walking with or without an appropriate walking aid (high walker on wheels, walker, rollator, or crutches) allowed in transfer and walking if necessary. ${ }^{[9]}$ Each activity is assessed on a three-point ordinal scale from $0-2$ points ( $0=$ not able to, despite human assistance and verbal cueing, $1=$ able to, with human assistance and/or verbal cueing from one or more persons, $2=$ able to safely, without human assistance or verbal cueing, use of a walking aid allowed) resulting in a total one-day CAS ranging from 0-6 points. ${ }^{[9]}$ Score of six indicates a completely independent ambulatory level. A three-day CAS is obtained by summing postoperative day one, two and three CASs (0-18 points). ${ }^{[8]}$

In the process of translation, a four-step procedure was followed as in other validation and reliability studies in the literature together with the recommendations of the Mapi Research Institute for linguistic validation. ${ }^{[17,18]}$ First, translation of the English version of the CAS into Turkish was approved by one of the developers of the CAS, Dr. Kristensen. Second, the English version of the scoring form and manual was translated into Turkish independently by a physiotherapist and orthopedician with advanced level of English. The translations were reviewed by the same persons and another physiotherapist and a consensus version was obtained, which was then translated back into English by an academician and a PhD student with advanced level of English. The original and back-translated English versions were compared, necessary corrections and language adaptations were performed, and the final Turkish version and back-translated English version of CAS scoring form and manual were obtained. The backtranslated English version was approved by Dr. Kristensen. The sample instrument was administered to 10 elderly people to test its comprehensibility before the final Turkish version of the CAS-TR (Appendix 1) was administered to the patients included in the present study.

Two researchers, an orthopedician and a physiotherapist administered the CAS-TR to patients at postoperative day one, two and three, and again 
30 days after surgery with an interval of one to two hours in a randomized order. The two researchers were blinded to each other's rating until end of study.

In addition, the Barthel index was applied to patients on postoperative days two and 30 for use in validity analysis. Originally, Barthel index was developed in 1965 and updated in 1989 and thus the modified Barthel index (MBI) was developed. Functional independence is evaluated in 10 items including transfers, mobility, stairs, feeding, bathing, dressing, grooming, bowels, bladder, and toilet use. Modified Barthel index has three different weights of five-point rating scales: a score range of 0-5 for bathing, personal hygiene (grooming), and ambulation/wheelchair; a score range of 0-10 for feeding, dressing, toilet transfer, bladder control, bowel control, and stair climbing; and a score range of 0-15 for chair/bed transfers and ambulation. A higher score represents a higher degree of independence in performing activity daily living (ADL). The scores for each item are summed and the total ranges from 0 (complete dependence) to 100 (independence in terms of ADL). ${ }^{[19,20]}$

\section{Statistical analysis}

Data analysis was performed using the SPSS version 16.0 for Windows (SPSS Inc., Chicago, IL,
USA). A value of $p$ less than 0.05 was considered to be statistically significant for a two-tailed test. Weighted Cohen's kappa coefficient was used to measure interrater reliability. Standard error of measurement (SEM) and $95 \%$ confidence interval for kappa coefficient were estimated. The convergent validity was analyzed with the correlation coefficient (Spearman test) between the CAS-TR and the Turkish version of MBI scales assessed at postoperative days 2 and 30 .

\section{RESULTS}

The majority of the fractures were type III fracture $(72.2 \%)$ according to Garden's classification. Demographic and baseline characteristics of the patients are shown in Table I. None of the patients were working actively. Mean total CAS-TR obtained in postoperative day one+day two+day three (threeday CAS) by rater 1 was 5.4 , and 5.3 by rater 2 , and with no systematic between rater difference $(\mathrm{p}=0.571)$.

Kappa value of $>0.90$ is considered perfect according to a study by Landis and Koch. ${ }^{[21]}$ The kappa value was $\geq 0.90$ for all one-day assessments and for the three-day CAS-TR, while the SEM ranged from 0 to 0.05 (Table II). The observed agreement ranged between $91.6 \%$ and $100 \%$ for all CASs.

\begin{tabular}{|c|c|c|c|c|}
\hline \multicolumn{5}{|c|}{ TABLE I } \\
\hline Variables & $\mathrm{n}$ & $\%$ & Mean \pm SD & Min-Max \\
\hline Age (year) & & & $78.1 \pm 7.9$ & $65-90$ \\
\hline Body mass index $\left(\mathrm{kg} / \mathrm{m}^{2}\right)$ & & & $26.5 \pm 3.4$ & $20-35$ \\
\hline \multicolumn{5}{|l|}{ Gender } \\
\hline Female & 24 & 66.7 & & \\
\hline Male & 12 & 33.3 & & \\
\hline Walking aid use before the fracture & 12 & 33.3 & & \\
\hline \multicolumn{5}{|l|}{ Fracture classification } \\
\hline Garden 2 & 2 & 5.5 & & \\
\hline Garden 3 & 26 & 72.2 & & \\
\hline Garden 4 & 8 & 22.2 & & \\
\hline Postoperative day 1 CAS-TR & & & $0.9 \pm 0.9$ & $0-3$ \\
\hline Postoperative day 2 CAS-TR & & & $1.9 \pm 0.8$ & $0-4$ \\
\hline Postoperative day 3 CAS-TR & & & $2.6 \pm 0.9$ & $1-5$ \\
\hline Three-day (Day 1+2+3) CAS-TR & & & $5.4 \pm 2.1$ & $1-11$ \\
\hline Postoperative day 30 CAS-TR & & & $5.6 \pm 0.8$ & $2-6$ \\
\hline Postoperative day 2 Barthel score & & & $38.1 \pm 13.9$ & $5-55$ \\
\hline Postoperative day 30 Barthel score & & & $79.1 \pm 18.1$ & $40-100$ \\
\hline
\end{tabular}




\begin{tabular}{|c|c|c|c|c|c|}
\hline \multicolumn{6}{|c|}{$\begin{array}{l}\text { TABLE II } \\
\text { version of } C\end{array}$} \\
\hline & \multicolumn{2}{|c|}{ Observed agreement } & \multirow[b]{2}{*}{ Kappa value } & \multirow[b]{2}{*}{$95 \% \mathrm{Cl}$} & \multirow[b]{2}{*}{ SEM } \\
\hline & $\mathrm{n}$ & $\%$ & & & \\
\hline First day CAS-TR & 36 & 100 & 1 & & 0 \\
\hline Second day CAS-TR & 33 & 91.6 & 0.90 & $0.802-0.99$ & 0.05 \\
\hline Third day CAS-TR & 36 & 100 & 1 & & 0 \\
\hline Total CAS-TR & 33 & 91.6 & 0.903 & $0.825-0.98$ & 0.04 \\
\hline $30^{\text {th }}$ day CAS-TR & 36 & 100 & 1 & & 0 \\
\hline
\end{tabular}

There were moderate positive correlations between day two and day 30 CAS-TR and Barthel scores $(r=0.334$ and 0.501 , respectively) (Table II). Moderate positive correlation was also found between Barthel transfer and mobility scores and CASs obtained on the $30^{\text {th }}$ day (Table III).

There were significantly positive correlations between days two, three and 30 CASs $(r=0.440,0.448$ and 0.404 , respectively).

\section{DISCUSSION}

The CAS was adapted linguistically into Turkish and almost perfect inter-rater reliability, high agreement and acceptable validity for Turkish patients were established in the present study. The study also showed that the CAS-TR is an applicable instrument to assess basic mobility status in Turkish patients with hip fracture.

Although the fracture is surgically repaired, permanent functional disability and ambulation loss may occur in patients with hip fractures. A previous study reported that the proportion of patients living in nursing homes increased from 15\% before to $30 \%$ after the hip fracture; the proportion of walking without any aid decreased from 76 to $36 \%$; and $43 \%$ of the patients lost their pre-fracture ability to mobilize outside their own home. ${ }^{[22]}$

Assessing patients' postoperative mobility levels and determining the proper and structural rehabilitation programs can reduce hospital stay, while improving mobility can lower the disability and mortality rates. ${ }^{[23-25]}$ Therefore, evaluation of mobility is important in patients with hip fracture. In the literature, there are some functional tests (Timed Up and Go, Self-Paced Walking, Berg Balance Scale) described to assess mobility after hip fracture. ${ }^{[26,27]}$ However, after surgical treatment, more demanding structural functional testing may be difficult in an elderly patient population in the acute postoperative period. The patient's simple daily activities can be observed by the clinician and simple mobility assessment can provide convenience for the clinician and the patient. CAS is a simple, reliable and useful tool defined to assess the basic mobility skills of all patients with hip fracture, and until independent ambulation is reached ${ }^{[9]}$ It provides an early forecasting of rehabilitation process and hospitalization, in addition to short- and longterm mortality. ${ }^{[8,10,11]}$ The CAS was widely used at

\begin{tabular}{|c|c|c|c|c|c|c|}
\hline \multicolumn{7}{|c|}{$\begin{array}{l}\text { TABLE III } \\
\text { sh version of } \mathrm{Cu}\end{array}$} \\
\hline & \multicolumn{3}{|c|}{ Postoperative day 2} & \multicolumn{3}{|c|}{ Postoperative day 30} \\
\hline & $\begin{array}{c}\text { Total } \\
\text { Barthel score }\end{array}$ & $\begin{array}{c}\text { Barthel } \\
\text { transfer score }\end{array}$ & $\begin{array}{c}\text { Barthel } \\
\text { mobility score }\end{array}$ & $\begin{array}{c}\text { Total } \\
\text { Barthel score }\end{array}$ & $\begin{array}{c}\text { Barthel } \\
\text { transfer score }\end{array}$ & $\begin{array}{c}\text { Barthel } \\
\text { mobility score }\end{array}$ \\
\hline \multicolumn{7}{|c|}{ Postoperative day 2 CAS-TR score } \\
\hline $\mathrm{p}$ & 0.046 & NS & 0.007 & & & \\
\hline$r$ & 0.334 & & 0.443 & & & \\
\hline \multicolumn{7}{|c|}{ Postoperative day 30 CAS-TR score } \\
\hline $\mathrm{p}$ & & & & 0.002 & 0.008 & 0.003 \\
\hline$r$ & & & & 0.501 & 0.433 & 0.476 \\
\hline
\end{tabular}


the majority of Danish hospital patients with hip fracture, ${ }^{[28]}$ and for more than five years included as an obligatory score in the Multidisciplinary Danish Hip Fracture Database. ${ }^{[10]}$ Also, the CAS was recently included in the Irish Hip Fracture Database.

The kappa value for the CAS-TR was calculated as 1 (perfect) for postoperative days one, three and 30, and $>0.90$ (almost perfect) for postoperative day two and the cumulated three-day CAS-TR scores. Correspondingly, Kristensen et al. ${ }^{[9]}$ reported kappa values $\geq 0.92$ for the three individual activities described in CAS and the total one-day CAS. Grana et al. ${ }^{[14]}$ estimated the kappa value for Italian version of CAS as 1 for postoperative day two (48 hours after surgery) and $\geq 0.95$ for the CAS at the three months of follow-up.

The observed agreement ranged between $91.6 \%$ and $100 \%$ for CAS-TR. Similarly, Kirstensen et al. ${ }^{[9]}$ reported ranges between $0.90 \%$ and $0.98 \%$ and Grana et al. ${ }^{[14]}$ reported ranges as 97.5 to $100 \%$. The overall almost perfect reliability and high agreement of the CAS, as confirmed in the present study, were also reported for the Spanish version of the CAS. ${ }^{[15]}$

The validity analysis showed that there is moderate positive correlation between CAS-TR and the Turkish version of modified Barthel scales assessed at postoperative days 2 and 30. Grana et al. ${ }^{[14]}$ had used Katz Activities of Daily Living scale for validity analysis of Italian version of CAS. Unlike our study results, they found a strong relationship between ADL scale and CAS scale; the reason for this different result may be the differences between rating of Katz and Barthel scales. The validity of CAS has been assessed in different ways in 15 studies and high to moderate correlations were reported by authors. ${ }^{[27]}$

There were significantly positive correlations between CASs obtained at postoperative days two, three, and the three-day CASs and day 30 CAS. This indicates that early mobility scores may be a determinant for the long-term mobility function skills. Also, the Italian version of CAS showed significantly positive correlation between 48 hours after surgery and three months of follow-up. ${ }^{[14]}$

Only patients with femoral neck fractures who underwent surgery with a hemiarthroplasty were included in this study, which can be considered a limitation. However, all orthopedic and geriatric patients, ${ }^{[27,28]}$ and patients undergoing any type of surgery can be assessed with the CAS for early evaluation of mobility status, and for planning of acute and post-acute rehabilitation. Also, Jønsson et al. ${ }^{[29]}$ assessed physical performance of patients undergoing acute high-risk abdominal surgery using the CAS. Further, determination of the CAS for long-term mobility level could not be examined, which can be considered another limitation of this study. Still, previous studies reported that the CAS is a valid predictor of length of hospitalization, discharge home, medical complications, and associated with 30-day and long-term (postoperative one and five years) mortality rates in older patients after hip fracture surgery. ${ }^{[8,10,11,27]}$

In conclusion, the results of this study showed that the CAS-TR is a reliable and valid tool for use in Turkish patients with hip fracture. The CAS can be implemented easily in acute care settings, and considered a useful instrument to monitor the basic mobility outcome during the early recovery period. We recommend the CAS-TR to be used for the assessment of basic mobility of patients with hip fracture in Turkey until independence is reached as well as for use in other frail patient groups.

\section{Declaration of conflicting interests}

The authors declared no conflicts of interest with respect to the authorship and/or publication of this article.

\section{Funding}

The authors received no financial support for the research and/or authorship of this article.

\section{REFERENCES}

1. Nazrun AS, Tzar MN, Mokhtar SA, Mohamed IN. A systematic review of the outcomes of osteoporotic fracture patients after hospital discharge: morbidity, subsequent fractures, and mortality. Ther Clin Risk Manag 2014;10:937-48.

2. Global Health and Aging-World Health Organization; 2011. Available at: https://www.who.int/ageing/en/

3. Abraham DS, Barr E, Ostir GV, Hebel JR, Golden J, GruberBaldini AL, et al. Residual Disability, Mortality, and Nursing Home Placement After Hip Fracture Over 2 Decades. Arch Phys Med Rehabil 2019;100:874-82.

4. Cauley JA. Burden of hip fracture on disability. Lancet Public Health 2017;2:e209-e10.

5. Bozkurt HH, Tokgöz MA, Yapar A, Atik OŞ. What is the importance of canal-to-diaphysis ratio on osteoporosisrelated hip fractures? Eklem Hastalik Cerrahisi 2019;30:296-300.

6. Halbert J, Crotty M, Whitehead C, Cameron I, Kurrle S, Graham S, et al. Multi-disciplinary rehabilitation after hip fracture is associated with improved outcome: A systematic review. J Rehabil Med 2007;39:507-12.

7. Hershkovitz A, Pulatov I, Brill S, Beloosesky Y. Can hipfractured elderly patients maintain their rehabilitation achievements after 1 year? Disabil Rehabil 2012;34:304-10.

8. Foss NB, Kristensen MT, Kehlet H. Prediction of postoperative morbidity, mortality and rehabilitation in 
hip fracture patients: the cumulated ambulation score. Clin Rehabil 2006;20:701-8.

9. Kristensen MT, Andersen L, Bech-Jensen R, Moos M, Hovmand B, Ekdahl C, et al. High intertester reliability of the cumulated ambulation score for the evaluation of basic mobility in patients with hip fracture. Clin Rehabil 2009;23:1116-23.

10. Kristensen MT, Öztürk B, Röck ND, Ingeman A, Palm H, Pedersen AB. Regaining pre-fracture basic mobility status after hip fracture and association with post-discharge mortality and readmission-a nationwide register study in Denmark. Age Ageing 2019;48:278-84.

11. Kristensen MT, Kehlet H. The basic mobility status upon acute hospital discharge is an independent risk factor for mortality up to 5 years after hip fracture surgery. Acta Orthop 2018;89:47-52.

12. Hulsbæk S, Larsen RF, Troelsen A. Predictors of not regaining basic mobility after hip fracture surgery. Disabil Rehabil 2015;37:1739-44.

13. Fitzgerald M, Blake C, Askin D, Quinlan J, Coughlan T, Cunningham C. Mobility one week after a hip fracture - can it be predicted? Int J Orthop Trauma Nurs 2018;29:3-9.

14. Grana E, Verzellotti S, Grassi FA, Ferriero G, Kristensen MT, Cisari C, et al. Cross-cultural validation of the Italian version of the Cumulated Ambulation Score. Int J Rehabil Res 2016;39:160-4.

15. Ariza-Vega P, Mora-Traverso M, Ortiz-Piña M, Ashe MC, Kristensen MT. Translation, inter-rater reliability, agreement, and internal consistency of the Spanish version of the cumulated ambulation score in patients after hip fracture. Disabil Rehabil 2019. [Online ahead of print]

16. Nieminen S, Satokari K. Classification of medial fractures of the femoral neck. Acta Orthop Scand 1975;46:775-81.

17. Available at: https://www.mapi-institute.com/ [April 05, 2020]

18. Acquadro C, Joyce CRB, Patrick DL, Ware JE, Wu AW. Linguistic Validation Manual for Patient-Reported Outcomes (PRO) Instruments. Lyon: Mapi Research Trust; 2004.

19. Mahoney FI, Barthel DW. Functional evaluation: The Barthel index. Md State Med J 1965;14:61-5.
20. Shah S, Vanclay F, Cooper B. Improving the sensitivity of the Barthel Index for stroke rehabilitation. J Clin Epidemiol 1989;42:703-9.

21. Landis JR, Koch GG. The measurement of observer agreement for categorical data. Biometrics 1977;33:159-74.

22. Osnes EK, Lofthus CM, Meyer HE, Falch JA, Nordsletten L, Cappelen I, et al. Consequences of hip fracture on activities of daily life and residential needs. Osteoporos Int 2004;15:567-74.

23. Schnell S, Friedman SM, Mendelson DA, Bingham KW, Kates SL. The 1-year mortality of patients treated in a hip fracture program for elders. Geriatr Orthop Surg Rehabil 2010;1:6-14.

24. Singh NA, Quine S, Clemson LM, Williams EJ, Williamson DA, Stavrinos TM, et al. Effects of high-intensity progressive resistance training and targeted multidisciplinary treatment of frailty on mortality and nursing home admissions after hip fracture: a randomized controlled trial. J Am Med Dir Assoc 2012;13:24-30.

25. Cooper R, Kuh D, Hardy R; Mortality Review Group; FALCon and HALCyon Study Teams. Objectively measured physical capability levels and mortality: systematic review and meta-analysis. Version 2. BMJ 2010;341:c4467.

26. Mendelsohn ME, Leidl DS, Overend TJ, Petrella RJ. Specificity of functional mobility measures in older adults after hip fracture: a pilot study. Am J Phys Med Rehabil 2003;82:766-74.

27. Ferriero G, Kristensen MT, Invernizzi M, Salgovic L, Bravini E, Sartorio F, et al. Psychometric properties of the Cumulated Ambulation Score: a systematic review. Eur J Phys Rehabil Med 2018;54:766-71.

28. Kristensen MT, Jakobsen TL, Nielsen JW, Jørgensen LM, Nienhuis RJ, Jønsson LR. Cumulated Ambulation Score to evaluate mobility is feasible in geriatric patients and in patients with hip fracture. Dan Med J 2012;59:A4464.

29. Jønsson LR, Ingelsrud LH, Tengberg LT, Bandholm T, Foss NB, Kristensen MT. Physical performance following acute high-risk abdominal surgery: a prospective cohort study. Can J Surg 2017;60:12616. 


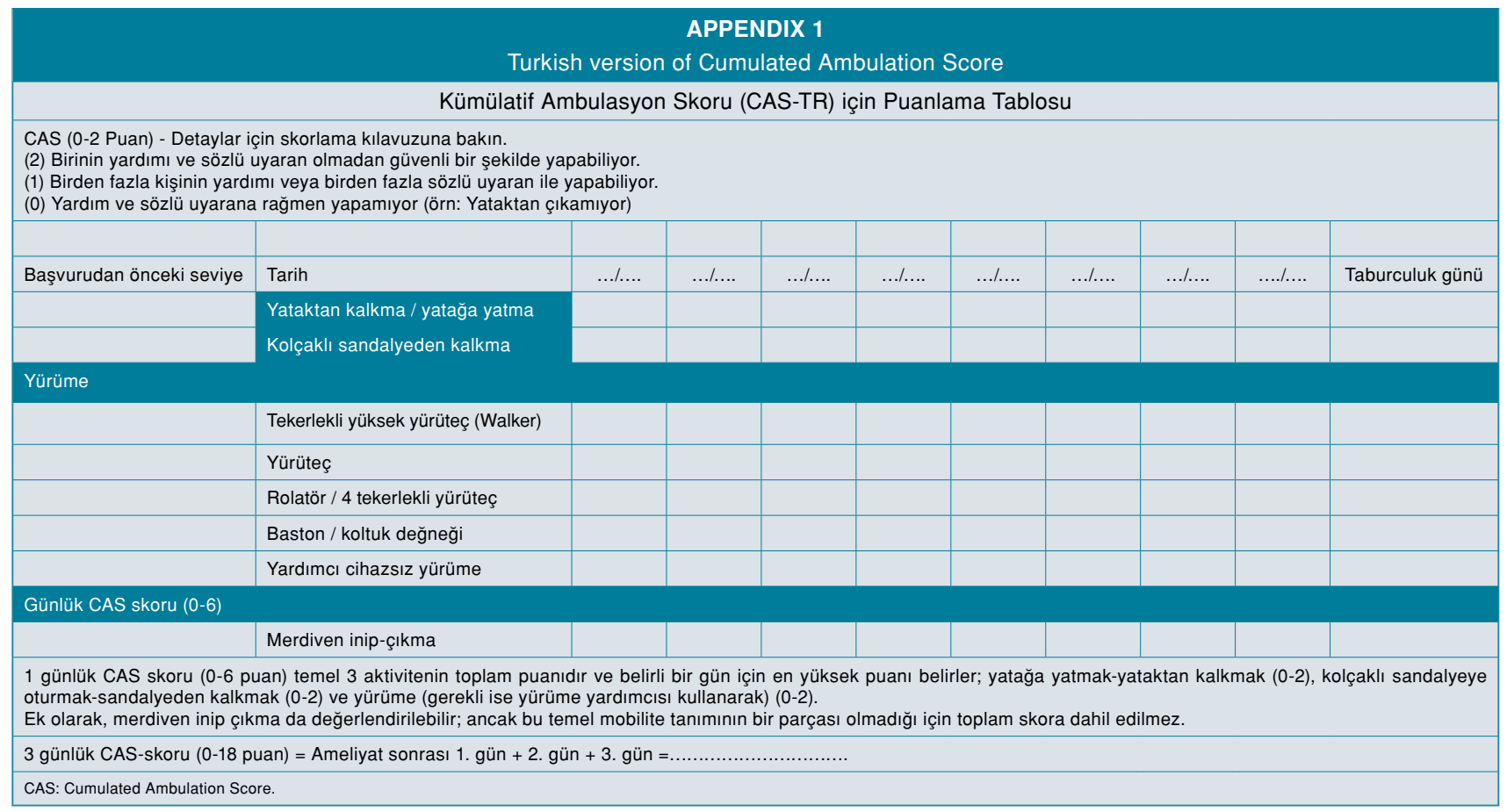

\section{KÜMÜLATIF AMBULASYON SKORU-TÜRKÇE VERSIYONU (CAS-TR)-KILAVUZU Turkish version of the Cumulated Ambulation Score (CAS-TR)-Manual}

\section{AÇIKLAMALAR VE UYGULAMA:}

CAS; [1] bağımsız ambulasyona ulaşana kadar temel hareketlilikteki (aşağıda tanımlanan) gelişmelerin günlük değerlendirilmesinde kullanılabilecek bir puanlama sistemidir.

- Yatağa yatmak ve yataktan kalkmak

- Kolçaklı sandalyeden ayağa kalkmak ve oturmak

- Kapalı ortamda yürüyüs

Üç aktivitenin her biri 0-2 puan, günlük skor (günlük CAS) 0-6 olarak puanlanır [2-5]

CAS'ın, rehabilitasyon süreci ve hastanede kalış süresi için erken gösterge sağlayan güvenilir ve kullanışı bir araç olduğu kanıtlanmıştır. Bunun amaçla, ameliyat sonrası ilk üç günün toplam (kümülatif) puanı CAS 0-18'i verir (Üç günlük CAS).

- CAS 0-18 (3 günlük CAS)[1]

- Postoperatif 1-3 gün için CAS >9 olmasının, 14 gün içinde taburculuk, doğrudan eve taburculuk, majör medikal komplikasyonlar yaşanmaması ve 30 günlük sağkalım için öngösterge olduğu kanıtlanmıştır.[1]

CAS içinde yer alan 3 aktivitenin puanlaması, 2009 güvenirlik çalışmasında tanımlanmıştır. ${ }^{[2]}$

Yatağa yatma ve yataktan kalkma: (Sırtüstü pozisyondan yatak kenarında oturmaya gelmek, yatak kenarındaki sandalyeye oturmak veya yatak kenarında ayakta durmak ve yatakta sırtüstü yatar pozisyona geri dönmek).

- Aktivite bağımsız yapıldığında 2 puan verilir: Bağımsız olarak, güvenlik nedeniyle bile olsa, sözlü uyaran veya birinin yardımının gerekli olmadığı anlamına gelir. Tüm yürüme yardımcıları kullanılabilir.

- Birinin yardımına intiyaç duyulduğunda 1 puan verilir: Birinin yardımı; sözlü uyaran, bir veya daha fazla kişiden alınan kapsamlı yardıma kadar her şeyi olabilir ve yardımcı araçları içerir.

- Yataktan çıkamayan hastalar için 0 puan verilir: Bu; yardımcı araç kullanımı da dahil, bir veya daha fazla kişiden alınan kapsamlı yardıma rağmen, hastaların ayağa kalkamayacağı veya bir sandalyede oturamayacağı anlamına gelir.

Kolçaklı bir sandalyeye oturup-kalkma: (Oturmadan-kalkmaya, ayakta durmadan-oturmaya)

- Aktivite bağımsız olarak yapıldığında 2 puan verilir: Bağımsız olarak, güvenlik nedeniyle bile olsa, sözlü ipucu veya birinin yardımının gerekli olmadığı anlamına gelir.

- Birinin yardımına intiyaç duyulduğunda 1 puan verilir: Birinin yardımı; sözlü uyaran, bir veya daha fazla kișiden alınan kapsamlı yardıma kadar her șeyi olabilir ve yardımcı araçları içerir.

- Sandalyeye oturamayan hastalar için 0 puan verilir: Bu, yardımcı araç kullanımı da dahil, bir veya daha fazla kişiden alınan fazla miktarda yardıma rağmen sandalyede oturamayan hastaları ifade eder.

Kapalı ortamda yürüyüs:

- Bir yürüme yardımcısıyla bağımsızıık sağlandığında 2 puan verilir: Bağımsız olarak, güvenlik nedeniyle bile olsa, sözlü uyaran veya birinin yardımının gerekli olmadığı anlamına gelir. Tüm yürüme yardımcıları kullanılabilir.

- Birinin yardımına intiyaç duyulduğunda 1 puan verilir: Birinin yardımı; sözlü uyaran, bir veya daha fazla kişiden alınan kapsamlı yardıma kadar her şeyi olabilir ve yürüme yardımcılarını da içerir.

- Yürüyemeyen hastalar için 0 puan verilir: Bu, yürüme yardımcıları kullanımı da dahil, bir veya daha fazla kişiden alınan fazla miktarda yardıma rağmen yürüyemeyen hastaları ifade eder.

References (selected)

1. Foss NB, Kristensen MT, Kehlet H. Prediction of postoperative morbidity, mortality and rehabilitation in hip fracture patients: the cumulated ambulation score. Clin Rehabil 2006;20:701-8.

2. Kristensen MT, Andersen L, Bech-Jensen R, Moos M, Hovmand B, Ekdahl C, et al. High intertester reliability of the cumulated ambulation score for the evaluation of basic mobility in patients with hip fracture. Clin Rehabil 2009;23:1116-23.

3. Kristensen MT, Jakobsen TL, Nielsen JW, Jørgensen LM, Nienhuis RJ, Jønsson LR. Cumulated Ambulation Score to evaluate mobility is feasible in geriatric patients and in patients with hip fracture. Dan Med J 2012;59:A4464.

4. Kristensen MT, Kehlet $\mathrm{H}$. Most patients regain prefracture basic mobility after hip fracture surgery in a fast-track programme. Dan Med J 2012;59:A4447.

5. Ferriero G, Kristensen MT, Invernizzi M, Salgovic L, Bravini E, Sartorio F, et al. Psychometric properties of the Cumulated Ambulation Score: a systematic review. Eur J Phys Rehabil Med 2018;54:766-71.

Turkish version by Dr ilker Çolak, MD; Emel Mete PT, MSc;.Tuğba Kuru Çolak, PT, PhD, after English version by Derek Curtis, PT, PhD and Morten Tange Kristensen, PT, PhD, Amager-Hvidovre Hospital, Copenhagen, Denmark. Contact person: Iliker Çolak, Email: drilkercolak@hotmail.com 